\title{
Game Edukasi Anak Menggunakan Metode Finite State Machine Berbasis Android
}

\author{
Aliffia Novsiyanti Ashari, Mohamad Jajuli, Budi Arif Dermawan \\ Jurusan Teknik Informatika, Fakultas Ilmu Komputer, Universitas Singaperbangsa Karawang \\ Jalan HS. Ronggo Waluyo, Karawang (41361), Telp. (0267) 641177

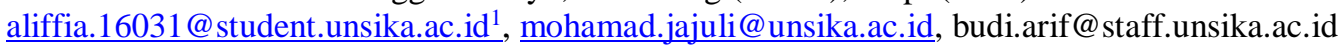

Diterima : 25 Juni 2020. Disetujui : 3 Oktober 2020. Dipublikasikan : 3 Oktober 2020.

\begin{abstract}
The learning media applied today are still conventional in nature. Therefore, this study designed a children's educational game using the Android-based finite state machine method, where the finite state machine method is an application flow control system. The application development method used is the Multimedia Development Life Cycle (MDLC) which has six stages namely concept, design, material collecting, assembly, testing, and distribution. The purpose of this application, is to evaluate children's knowledge in lessons, by utilizing interactive media such as images, 2D animated transitions and music. Based on the results of the application testing with alpha testing, the application function runs well and the results of beta testing with eight question questionnaires filled out by 32 students in grade 1 (one) Sukamandi II Elementary School obtained a percentage of $98.6 \%$, so the application is worth using. From manual testing, the results of children's knowledge in Mathematics are 86.2\%, Indonesian $85.3 \%$ and English 73.8\% and evaluation results using game applications in Mathematics lessons 97.8\%, Indonesian 95.6\% and English 92.5\%, so it can be concluded that children's knowledge in lessons has increased after using educational game applications, namely $11.6 \%$ in Mathematics, $12.5 \%$ Indonesian Language lessons and 18.7\% English Language lessons, so applications This is effective to improve children's learning abilities.
\end{abstract}

Keywords: child learning comprehension, education, finite state machine, learning media

Abstrak - Media belajar yang diterapkan saat ini masih bersifat konvensional. Maka dari itu, penelitian ini merancang game edukasi anak menggunakan metode finite state machine berbasis android, dimana metode finite state machine ini merupakan sistem kontrol alur aplikasi. Metodologi pengembangan aplikasi yang digunakan adalah Multimedia Development Life Cycle (MDLC) yang memiliki enam tahapan yaitu concept, design, material collecting, assembly, testing dan distribution dengan metode Finite State Machine (FSM). Metode finite state machine merupakan sistem kontrol alur aplikasi memiliki sifat yang reaktif dan real time, memiliki tiga aspek yaitu state (kondisi), event (kejadian), dan action (aksi). Tujuan adanya aplikasi ini, untuk mengevaluasi pengetahuan anak pada pelajaran, dengan memanfaatkan media interaktif seperti gambar, animasi 2D transisi dan musik. Berdasarkan hasil uji aplikasi dengan alpha testing, fungsi aplikasi berjalan dengan baik dan hasil dari beta testing dengan kuisioner delapan pertanyaan yang diisi oleh 32 siswa kelas 1 (satu) Sekolah Dasar Negeri Sukamandi II diperoleh presentase 98,6\%, sehingga aplikasi layak digunakan. Dari pengujian manual didapatkan hasil pengetahuan anak pada pelajaran Matematika sebesar 86,2\%, Bahasa Indonesia 85,3\% dan Bahasa Inggris 73,8\% dan hasil evaluasi menggunakan aplikasi game pada pelajaran Matematika sebesar 97,8\%, Bahasa Indonesia 95,6\% dan Bahasa Inggris 92,5\%, sehingga dapat disimpulkan bahwa pengetahuan anak dalam pelajaran mengalami peningkatan setelah menggunakan aplikasi game edukasi yaitu 11,6\% pada pelajaran Matematika, 12,5\% pelajaran Bahasa Indonesia dan 18,7\% pelajaran Bahasa Inggris, sehingga aplikasi ini efektif untuk meningkatkan kemampuan belajar anak.

Kata kunci: pemahaman belajar anak, pendidikan, finite state machine, media belajar

\section{PENDAhUluan}

Teknologi mengalami perkembangan yang sangat pesat baik dari segi kesehatan, ekonomi industri maupun pendidikan. Pendidikan merupakan hal yang paling penting dalam mengembangkan potensi yang ada pada diri manusia dan harus diterapkan sejak dini. Pendidikan juga erat kaitannya dengan teknologi. Teknologi dapat dimanfaatkan sebagai media belajar. Namun, media belajar yang diterapkan hingga saat ini masih bersifat konvensional. Artinya, siswa mengandalkan guru menjelaskan materi, memberi contoh, mengajukan pertanyaan, dan memberikan tugas, sehingga kegiatan siswa hanya mencatat penjelasan dari guru. Menurut Crawford situasi belajar ini disebut learning with effort [1]. 
Teknologi mengalami perkembangan yang sangat pesat baik dari segi kesehatan, ekonomi industri maupun pendidikan. Pendidikan merupakan hal yang paling penting dalam mengembangkan potensi yang ada pada diri manusia dan harus diterapkan sejak dini. Pendidikan juga erat kaitannya dengan teknologi. Teknologi dapat dimanfaatkan sebagai media belajar. Namun, media belajar yang diterapkan hingga saat ini masih bersifat konvensional. Artinya, siswa mengandalkan guru menjelaskan materi, memberi contoh, mengajukan pertanyaan, dan memberikan tugas, sehingga kegiatan siswa hanya mencatat penjelasan dari guru.

Android merupakan sistem operasi untuk perangkat seluler [2]. Android dapat dimanfaatkan untuk membuat sebuah aplikasi game edukasi pengetahuan anak dalam pelajaran menggunakan metode finite state machine berbasis android. Metode finite state machine merupakan sistem kontrol alur aplikasi memiliki sifat yang reaktif dan real time, memiliki tiga aspek yaitu state (kondisi), event (kejadian), dan action (aksi) [3], sehingga mampu menerima inputan dan mengeluarkan sebuah output serta bisa bertansisi dari satu state ke state lainnya berdasarkan input dan fungsi transisinya. Dengan adanya hal tersebut, maka dibuatlah aplikasi game edukasi anak menggunakan metode finite state machine berbasis android, untuk mengatasi dan mengevaluasi permasalahan anak yang dalam pelajaran sulit berkembang, mudah bosan dan tidak ada kemauan berusaha saat kegiatan belajar mengajar sedang berlangsung.

\section{METODE PENELITIAN}

Metodologi penelitian yang digunakan dalam pengembangan aplikasi game edukasi anak berbasis android adalah Multimedia Development Life Cycle (MDLC). Metodologi pengembangan multimedia ini terdiri dari enam tahap [5], yaitu:

\section{Konsep (Concept)}

Dalam tahap ini ingin mengetahui pemahaman anak dalam pelajaran, sehingga dilakukan wawancara kepada guru Sekolah Dasar kelas 1 (satu). Selain itu, mengetahui kurikulum yang digunakan dalam kegiatan belajar mengajar di Sekolah Dasar kelas 1 (satu). Tahap konsep ini terdiri dari tiga, yaitu:

1) Analisis Permasalahan

Dalam tahap ini ingin mengetahui pengetahuan anak dalam pelajaran Matematika, Bahasa Indonesia dan Bahasa Inggris, sehingga dilakukan wawancara kepada guru Sekolah Dasar kelas 1 (satu). Selain itu, mengetahui kurikulum yang digunakan dalam kegiatan belajar mengajar di Sekolah Dasar kelas 1 (satu).
2) Analisis Kebutuhan Software

Tahap ini menjelaskan software dan hardware yang digunakan untuk pembuatan program dalam membangun aplikasi game edukasi anak.

3) Analisis Pengguna Software

Pada tahap ini, menentukan sasaran pengguna aplikasi game edukasi anak.

\section{Perancangan (Design)}

Perancangan adalah penjelasan untuk setiap unsur - unsur yang akan dibuat seperti desain sistem, alur permainan, serta peran apa saja yang dapat dilakukan oleh user atau pengguna. Perancangan dibagi menjadi 2 (dua), yaitu:

1) Design Software

Design software ini, menggunakan Unified Model Language (UML) Diagram.

2) Design Game

Design dari suatu metode yang dikembangkan dalam perancangan aplikasi multimedia dibuat storyboard dan struktur navigasi.

\section{Pengumpulan Bahan (Material Collecting)}

Tahap ini adalah tahapan untuk mengumpulkan semua objek yang menjadi bagian dari game edukasi. Hasil dari wawancara dengan guru dan bahan-bahan dari buku siswa serta bahan pendukung seperti: gambar, animasi, foto, audio dan lain-lain dikumpulkan untuk melanjutkan ke tahap berikutnya.

\section{Perakitan (Assembly)}

Bahan-bahan yang sudah terkumpul berdasarkan perancangan pada tahap design seperti storyboard, struktur navigasi, dan bahan pendukung lainnya, selanjutnya pada tahap ini dilakukan perakitan. Dalam tahap ini juga dilakukan pembuatan program dan pengimplementasian metode finite state machine di dalam program, sehingga menjadikan aplikasi yang akan mempermudah anak-anak untuk belajar Matematika, Bahasa Indonesia dan Bahasa Inggris.

\section{Pengujian (Testing)}

Tahap ini dilakukan untuk mengetahui kekurangan dan tingkat kepuasan bagi yang menggunakan aplikasi juga mampu memperbaiki aplikasi yang dibuat agar pengguna nyaman dalam menggunakannya. Untuk melakukan pengujian, digunakan beberapa metode pengujian yaitu pengujian Alpha dan Beta Testing. 
1) Alpha testing

Pengujian alpha ini dilakukan oleh pembuat sendiri dengan menguji tampilan (interface), menu, fungsi tombol, gambar, teks dan audio yang dihasilkan.

2) Beta testing

Pengujian beta merupakan pengujian yang dilakukan langsung oleh pengguna.

\section{HASIL DAN PEMBAHASAN}

Hasil penelitian yang telah dilakukan adalah bagaimana mengatasi dan mengevaluasi permasalahan anak yang dalam pelajaran kesulitan berkembang, mudah bosan dan tidak ada kemauan berusaha, sebagai berikut:

\section{A. Konsep (Concept)}

Aplikasi game edukasi adalah permainan quiz yang mengedukasi anak dengan materi pembelajaran untuk anak Sekolah Dasar kelas 1(satu). Materi yang disajikan terdiri dari 3 mata pelajaran yaitu Matematika, Bahasa Indonesia, dan Bahasa Inggris, dilengkapi dengan multimedia sebagai media interaktif yaitu dengan perpaduan teks, gambar, dan audio dalam mengisi soal.

1) Analisis Permasalahan

Hasil wawancara dengan salah satu guru SDN Sukamandi II yaitu Kurikulum yang digunakan di Sekolah Dasar Negeri Sukamandi II adalah Kurikulum 2013 (kurtilas) yang menitik beratkan pada sikap dan menggunakan metode pembelajaran $5 \mathrm{M}$, yaitu mengamati, menanya, mengumpulkan informasi atau mencoba, mengasosiasi, mengomunikasikan.

2) Analisis Kebutuhan Software

\section{Software}

Software untuk membuat aplikasi ini sebagai berikut:

a. Android Studio digunakan untuk pembuatan game.

b. Adobe XD untuk membuat design pada game.

c. Windows 10 sebagai sistem Operasi.

d. Microsoft Visio 2016, aplikasi yang berfungsi untuk membuat use case dan activity diagram.

e. SQLite, yaitu software system manajemen database yang digunakan untuk game yang menyimpan soal pertanyaan beserta jawabannya.

\section{Hardware}

a. Hardware yang digunakan pembuat untuk membuat aplikasi adalah Asus VivoBook A442U Intel Core-i5-7200U, 3.1Ghz, RAM 4GB dan HDD 1TB. b. Hardware yang digunakan user adalah Smartphone Android 7(Nougaht)/API Level 25, RAM 1/2GB. Hardware ini digunakan oleh user.

\section{Pengguna Software}

Pengguna aplikasi adalah anak Sekolah Dasar (SD) kelas 1 (satu), agar anak dapat mengulas kembali pelajaran yang sudah diajarkan di sekolah walaupun penggunaannya dalam pengawasan orang tua.

\section{B. Perancangan (Design)}

\section{Design Software}

1) Use Case Diagram Game Edukasi

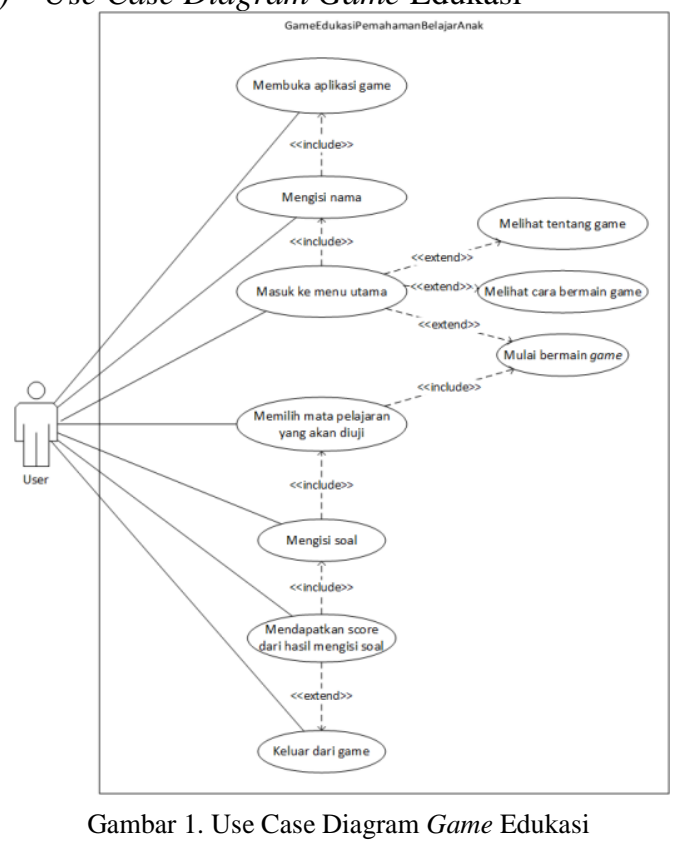

Dari Use Case Diagram yang sudah didefinisikan pada Gambar 1, maka dapat dibuat skenario Use Case pada Tabel I sampai dengan Tabel VII.

TABEL I. SKENARIO USE CASE MEMBUKA APLIKASI GAME

\begin{tabular}{|c|c|}
\hline Nama Use Case & \multicolumn{1}{c|}{$\begin{array}{c}\text { Game Edukasi Pemahaman Belajar } \\
\text { Anak }\end{array}$} \\
\hline Skenario & \multicolumn{1}{c|}{ Membuka Aplikasi Game } \\
\hline Aktor & \multicolumn{1}{c}{ User } \\
\hline Deskripsi & $\begin{array}{l}\text { User membuka aplikasi game edukasi } \\
\text { anak. }\end{array}$ \\
\hline
\end{tabular}

TABEL II. SKENARIO USE CASE MENGISI NAMA

\begin{tabular}{|c|c|}
\hline Nama Use Case & $\begin{array}{c}\text { Game Edukasi Pemahaman Belajar } \\
\text { Anak }\end{array}$ \\
\hline Skenario & Mengisi Nama \\
\hline Aktor & User \\
\hline Deskripsi & User mengisi nama terlebih dahulu. \\
\hline
\end{tabular}


TABEL III. SKENARIO USE CASE MENU UTAMA

\begin{tabular}{|c|c|}
\hline Nama Use Case & \multicolumn{1}{c|}{$\begin{array}{c}\text { Game Edukasi Pemahaman Belajar } \\
\text { Anak }\end{array}$} \\
\hline Skenario & Masuk ke Menu Utama \\
\hline Aktor & \multicolumn{1}{|c|}{ User } \\
\hline Deskripsi & $\begin{array}{l}\text { User dapat memilih salah satu menu } \\
\text { dari menu utama. User dapat melihat } \\
\text { terlebih dahulu informasi tentang game } \\
\text { atau informasi cara bermain game dan } \\
\text { juga bisa langsung bermain game. }\end{array}$ \\
\hline
\end{tabular}

TABEL IV. SKENARIO USE CASE PILIH PELAJARAN

\begin{tabular}{|c|c|}
\hline Nama Use Case & $\begin{array}{c}\text { Game Edukasi Pemahaman Belajar } \\
\text { Anak }\end{array}$ \\
\hline Skenario & Pilih Pelajaran \\
\hline Aktor & User \\
\hline Deskripsi & $\begin{array}{l}\text { User memilih pelajaran yang akan } \\
\text { diujikan. }\end{array}$ \\
\hline
\end{tabular}

TABEL V. SKENARIO USE CASE MENGISI SOAL

\begin{tabular}{|c|c|}
\hline Nama Use Case & \multicolumn{1}{|c|}{$\begin{array}{c}\text { Game Edukasi Pemahaman Belajar } \\
\text { Anak }\end{array}$} \\
\hline Skenario & \multicolumn{1}{|c|}{ User Soal } \\
\hline Aktor & \multicolumn{1}{|c|}{$\begin{array}{c}\text { User mengisi soal setelah memilih } \\
\text { pelajaran yang diujikan. }\end{array}$} \\
\hline Deskripsi
\end{tabular}

TABEL VI. SKENARIO USE CASE MENDAPATKAN SCORE

\begin{tabular}{|c|l|}
\hline Nama Use Case & \multicolumn{1}{|c|}{$\begin{array}{c}\text { Game Edukasi Pemahaman Belajar } \\
\text { Anak }\end{array}$} \\
\hline Skenario & \multicolumn{1}{|c|}{ Mendapatkan Score } \\
\hline Aktor & \multicolumn{1}{|c|}{ User } \\
\hline Deskripsi & $\begin{array}{l}\text { User mendapatkan score dari hasil } \\
\text { mengisi soal. }\end{array}$ \\
\hline
\end{tabular}

TABEL VII. SKENARIO USE CASE KELUAR GAME

\begin{tabular}{|c|c|}
\hline Nama Use Case & $\begin{array}{c}\text { Game Edukasi Pemahaman Belajar } \\
\text { Anak }\end{array}$ \\
\hline Skenario & Keluar Game \\
\hline Aktor & User \\
\hline Deskripsi & $\begin{array}{l}\text { User dapat memilih untuk keluar dari } \\
\text { game setelah selesai bermain game dan } \\
\text { mendapatkan score dari hasil mengisi } \\
\text { soal yang telah diujikan. }\end{array}$ \\
\hline
\end{tabular}

2) Activity Diagram

a. Activity Diagram Play Game

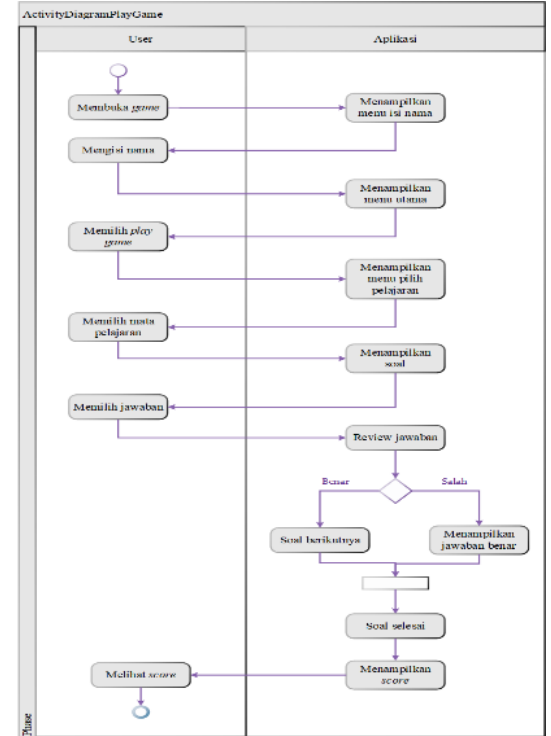

Gambar 2. Activity Diagram Play Game

b. Activity Diagram About Game

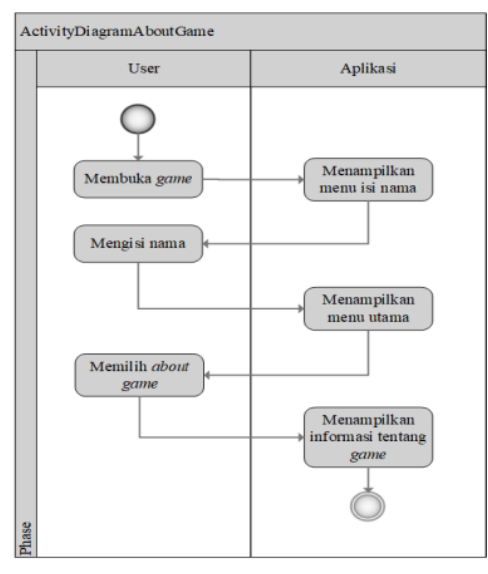

Gambar 3. Activity Diagram About Game

c. Activity Diagram Cara Bermain Game

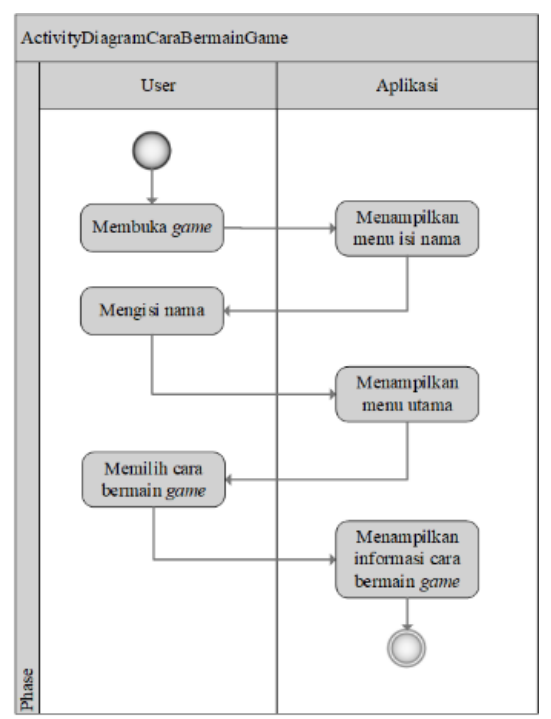

Gambar 4. Activity Diagram Cara Bermain Game 


\section{Design Game}

1) Storyboard

TABEL VIII. STORYBOARD GAME

\begin{tabular}{|c|c|c|}
\hline $\begin{array}{l}\text { Nama } \\
\text { Tampilan }\end{array}$ & Storyboard & Deskripsi \\
\hline Splash Screen & ImageView & $\begin{array}{lr}\text { Tampilan pertama } \\
\text { sementara yang } \\
\text { muncul beberapa detik, } \\
\text { terdiri dari gambar dan } \\
\text { text "Game Edukasi } \\
\text { Anak" }\end{array}$ \\
\hline Menu Isi Nama & 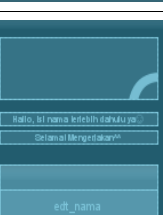 & $\begin{array}{l}\text { Pada menu ini terdapat } \\
\text { edit text dan tombol } \\
\text { masuk, yang mana } \\
\text { pada fungsi edit text } \\
\text { anak mengisi nama } \\
\text { terlebih dahulu. }\end{array}$ \\
\hline & & \\
\hline Menu Utama & 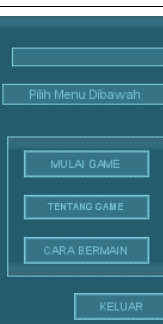 & $\begin{array}{l}\text { Menu utama ini berisi } \\
\text { tombol play game, } \\
\text { tentang game, dan cara } \\
\text { bermain game, dan } \\
\text { keluar. }\end{array}$ \\
\hline $\begin{array}{l}\text { Halaman About } \\
\text { Game }\end{array}$ & ImageView & $\begin{array}{l}\text { Halaman ini } \\
\text { memberikan informasi } \\
\text { aplikasi game edukasi. }\end{array}$ \\
\hline $\begin{array}{l}\text { Halaman Cara } \\
\text { Bermain Game }\end{array}$ & ImageView & $\begin{array}{l}\text { Halaman ini } \\
\text { memberikan informasi } \\
\text { cara bermain game } \\
\text { edukasi. }\end{array}$ \\
\hline
\end{tabular}

\begin{tabular}{|c|c|c|}
\hline $\begin{array}{l}\text { Nama } \\
\text { Tampilan }\end{array}$ & Storyboard & Deskripsi \\
\hline $\begin{array}{ll}\text { Menu } & \text { Pilih } \\
\text { Pelajaran } & \end{array}$ & 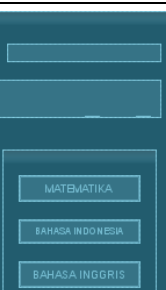 & $\begin{array}{l}\text { Pada menu ini terdapat } \\
3 \text { tombol mata } \\
\text { pelajaran yang dapat } \\
\text { dipilih, yaitu } \\
\text { Matematika, Bahasa } \\
\text { Indonesia dan } \\
\begin{array}{l}\text { Ingghis. } \\
\text { ngasa }\end{array}\end{array}$ \\
\hline $\begin{array}{l}\text { Halaman Quiz } \\
\text { Matematika }\end{array}$ & 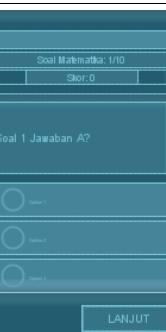 & $\begin{array}{l}\text { Halaman ini berisikan } \\
\text { soal-soal Matematika. }\end{array}$ \\
\hline $\begin{array}{ll}\text { Halaman } & \text { Quiz } \\
\text { Bahasa } & \\
\text { Indonesia } & \end{array}$ & 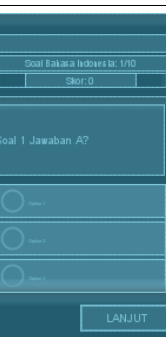 & $\begin{array}{lr}\text { Halaman ini berisikan } \\
\text { soal-soal } & \text { Bahasa } \\
\text { Indonesia. } & \end{array}$ \\
\hline $\begin{array}{l}\text { Halaman Quiz } \\
\text { Bahasa Inggris }\end{array}$ & 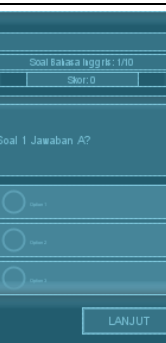 & $\begin{array}{l}\text { Halaman ini berisikan } \\
\text { soal-soal } \quad \text { Bahasa } \\
\text { Inggris. }\end{array}$ \\
\hline $\begin{array}{l}\text { Halaman } \\
\text { Muncul Score } \\
\text { Matematika }\end{array}$ & 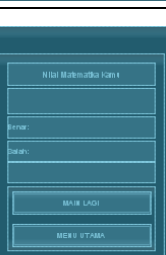 & $\begin{array}{lr}\text { Pada halaman ini, } & \text { skor } \\
\text { muncul } & \text { sker } \\
\text { Matematika setelah } \\
\text { user menjawab } & 10 \text { soal } \\
\text { pertanyaan tentang } & \text { pelajaran Matematika. }\end{array}$ \\
\hline $\begin{array}{l}\text { Halaman Score } \\
\text { Bahasa } \\
\text { Indonesia }\end{array}$ & 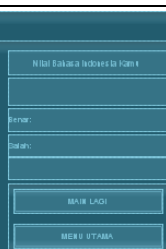 & 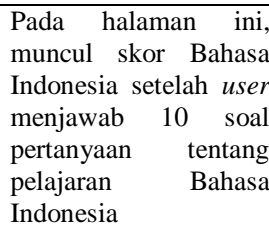 \\
\hline
\end{tabular}




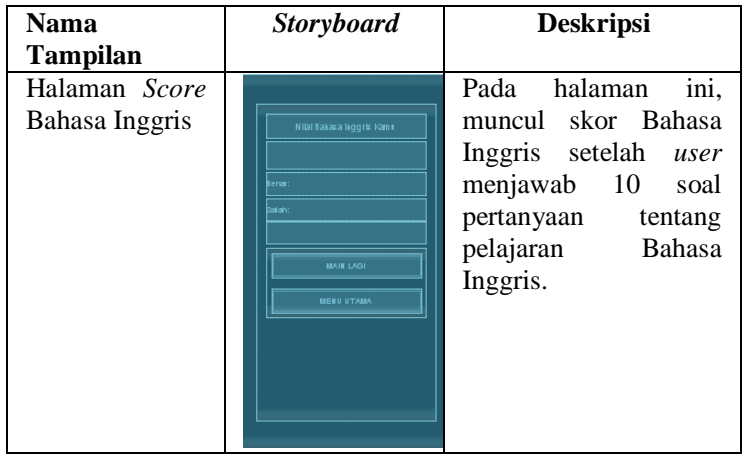

a. Struktur Navigasi

Struktur navigasi merupakan alur permainan setiap scene pada aplikasi, seperti yang ditunjukkan pada Gambar 5.

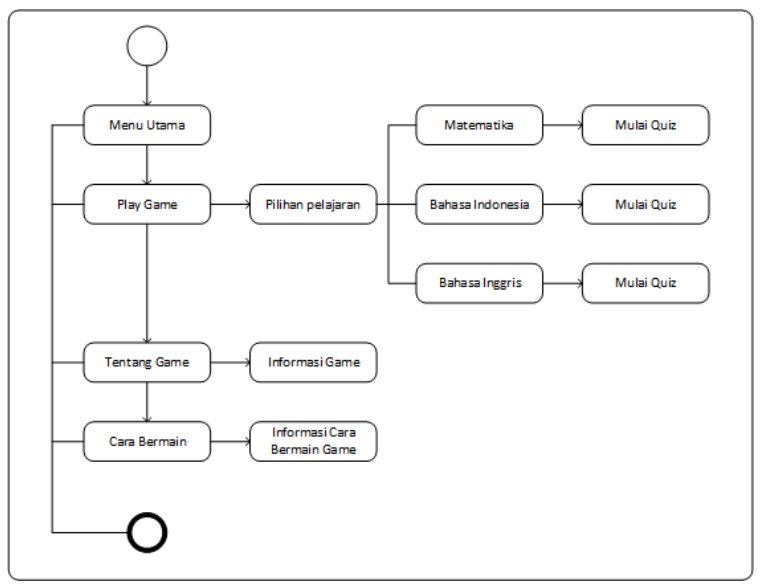

Gambar 5. Struktur Navigasi Game Edukasi Anak

b. Alur Finite State Machine

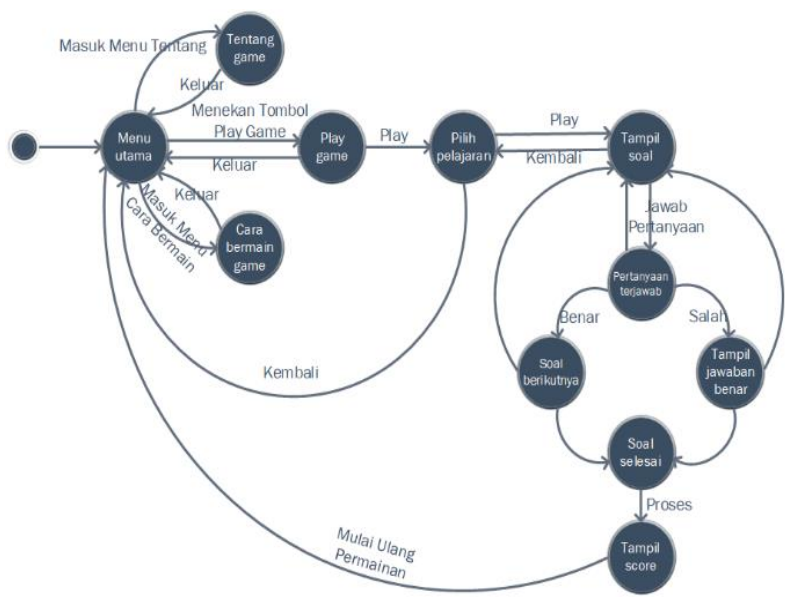

Gambar 6. Alur Finite State Machine

Berikut penjelasan mengenai penerapan finite state machine berupa rule perilaku IF/THEN, dimana rule tersebut menjelaskan hubungan antara input/output perilaku Finite State Machine sistem game dari Gambar 6.
1. IF Menu Utama AND Masuk Menu Tentang THEN Menu Tentang.

2. IF Menu Tentang AND Keluar THEN Menu Utama.

3. IF Menu Utama AND Masuk Menu Cara Bermain Game THEN Menu Cara Bermain Game.

4. IF Menu Cara Bermain Game AND Exit THEN Menu Utama.

5. IF Menu Utama AND Menekan Tombol Play Game THEN Play Game.

6. IF Play Game AND Play THEN Pilih Pelajaran.

7. IF Pilih Pelajaran AND Kembali THEN Menu Utama.

8. IF Pilih Pelajaran AND Play THEN Tampil Soal.

9. IF Tampil Soal AND Kembali THEN Pilih Pelajaran.

10. IF Pertanyaan Terjawab AND Jawaban Salah THEN Tampil Jawaban Benar.

11. IF Pertanyaan Terjawab AND Jawaban Benar THEN Soal Berikutnya.

12. IF Soal Selesai AND Proses THEN Tampil Score.

13. IF Tampil Score AND Mulai Ulang Permainan THEN Menu Utama.

TABEL IX. TRANSISI FINITE STATE MACHINE (FSM)

\begin{tabular}{|c|c|c|}
\hline \multirow{2}{*}{ Current State } & \multicolumn{2}{|c|}{ Next State } \\
\cline { 2 - 3 } & 0 & $\mathbf{1}$ \\
\hline Menu Utama & Menu Utama & Tentang Game \\
\hline Menu Utama & Menu Utama & Cara Bermain Game \\
\hline Menu Utama & Menu Utama & Play Game \\
\hline Play Game & Menu Utama & Pilih Pelajaran \\
\hline Pilih Pelajaran & Menu Utama & Tampil Soal \\
\hline Tampil Soal & Pilih Pelajaran & $\begin{array}{c}\text { Pertanyaan } \\
\text { Terjawab }\end{array}$ \\
\hline Pertanyaan & Tampil Jawaban & Soal Berikutnya \\
Terjawab & benar & Soal Selesai \\
\hline Soal & Pertanyaan & Terjawab \\
\hline Berikutnya & Soal Selesai & Tampil Score \\
\hline Tampil Selesai & Tampil Score & Menu Utama \\
\hline
\end{tabular}

\section{Pengumpulan Bahan (Material Collecting)}

Tahap ini dilakukan pengumpulan materi atau bahan untuk pembuatan aplikasi game edukasi anak. Bahan atau materi yang dikumpulkan adalah gambar yang digunakan yaitu 2D transisi untuk splash screen, PNG dan JPEG untuk gambar yang dimasukkan ke dalam soal. Bahan selanjutnya adalah file audio correct dan wrong ketika player menjawab pertanyaan salah atau benar, backsound serta audio effect yang diperoleh melalui website dengan format .mp3, dan tombol-tombol yang berfungsi sebagai petunjuk navigasi pada game serta materi yang dijadikan soal pertanyaan dari masing-masing pelajaran yang didapatkan dari buku tema 5 dan 6 
serta buku paket bahasa Inggris kelas 1 Sekolah Dasar pada kurikulum 2013.

\section{Perakitan (Assembly)}

Tahap ini menggabungkan bahan atau material yang sudah dikumpulkan. Selain bahan atau material, perakitan aplikasi ini juga dibuat berdasarkan tahap desain. Pengkodean aplikasi ini menggunakan tools Android Studio. Setelah pengkodean aplikasi ini selesai dilanjutkan proses build file.apk, sehingga aplikasi dapat diakses melalui smartphone android. Berikut hasil perakitan menggunakan tools Android Studio.

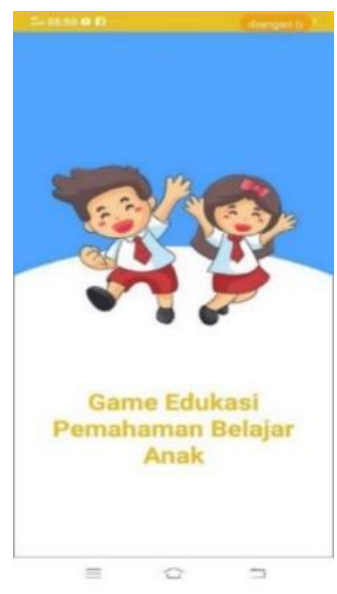

Gambar 7. Splash Screen

Splash Screen pada Gambar 7 adalah halaman splash screen yang muncul beberapa detik ketika animasi 2D transisi telah melakukan visibility.
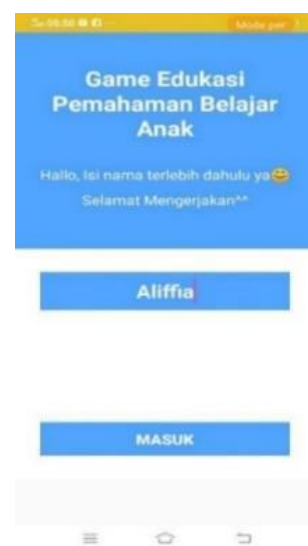

Gambar 8. Menu Isi Nama

Menu Isi Nama yang ditunjukkan Gambar 8 merupakan halaman untuk user mengisi nama terlebih dahulu.

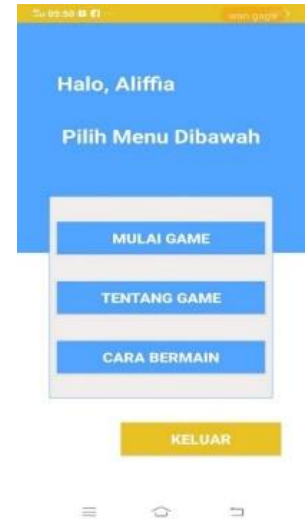

Gambar 9. Menu Utama

Gambar 9 merupakan menu utama pada aplikasi yang terdiri dari tombol mulai game, tentang game, cara bermain game dan tombol keluar.

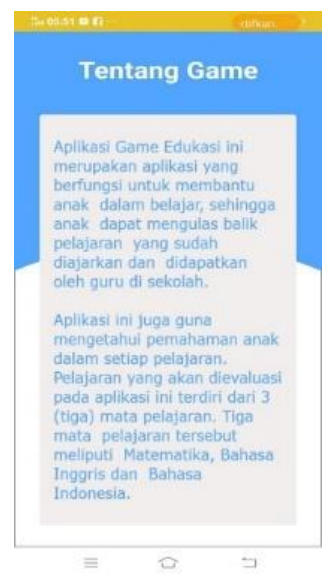

Gambar 10. Halaman About Game

Halaman about game pada Gambar 10 berisi informasi tentang game edukasi anak.

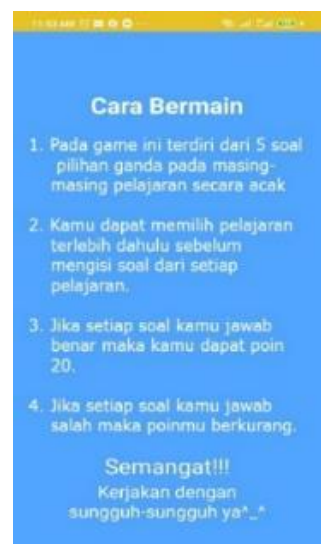

Gambar 11. Halaman Cara Bermain Game

Gambar 11 merupakan halaman cara bermain game yang berisikan informasi cara bermain game edukasi anak. 


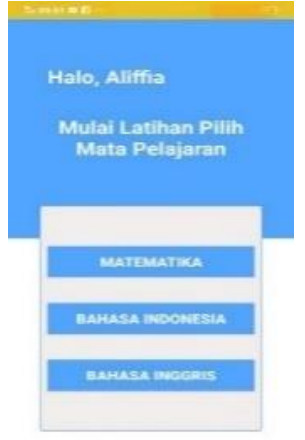

Gambar 12. Menu Pilih Pelajaran

Halaman menu pilih pelajaran yang ditunjukkan pada Gambar 12 adalah menu untuk user dalam memilih pelajaran yang akan diujikan.

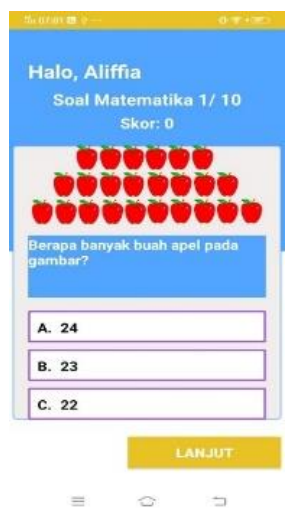

Gambar 13. Halaman Quiz Matematika

Halaman quiz matematika pada Gambar 13 merupakan halam user untuk mulai menjawab soal Matematika yang sudah ditampilkan.

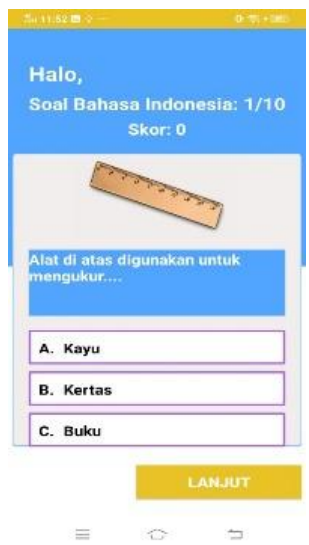

Gambar 14. Halaman Quiz Bahasa Indonesia

Halaman quiz Bahasa Indonesia pada Gambar 14 merupakan halaman user untuk mulai menjawab soal Bahasa Indonesia yang sudah ditampilkan.

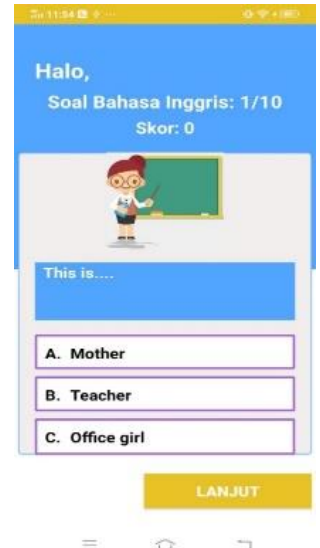

Gambar 15. Halaman Quiz Bahasa Inggris

Halaman quiz Bahasa Inggris yang ditunjukkan pada Gambar 15 adalah halaman user untuk mulai menjawab soal Bahasa Indonesia yang sudah ditampilkan.

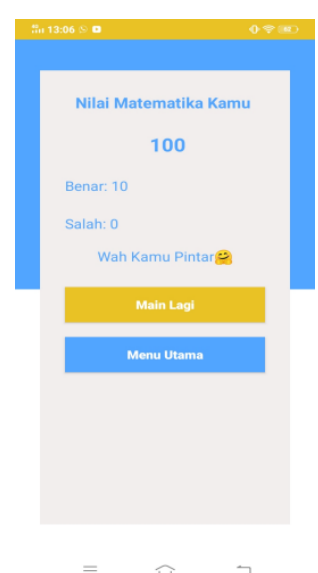

Gambar 16. Halaman Muncul Score Matematika

Gambar 16 adalah halaman score Matematika yang muncul ketika soal selesai dikerjakan.

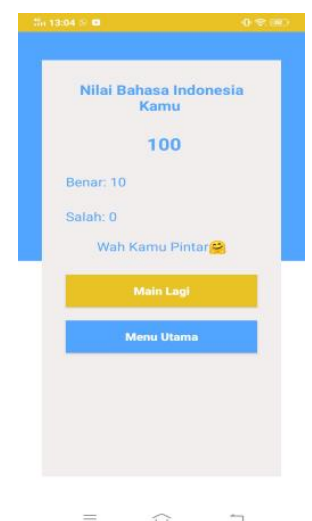

Gambar 17. Halaman Muncul Score Bahasa Indonesia

Halaman score Bahasa Indonesia pada Gambar 17 adalah halaman yang muncul ketika soal selesai dikerjakan. 


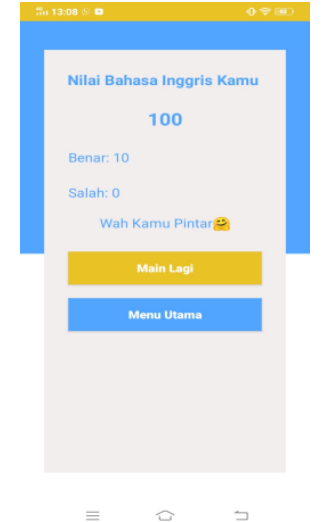

Gambar 18. Halaman Muncul Score Bahasa Inggris

Gambar 18 adalah halaman score Bahasa Inggris yang muncul ketika soal selesai dikerjakan.

\section{E. Pengujian (Testing)}

Tahap pengujian adalah tahap untuk mengetahui apakah tampilan aplikasi sudah sesuai dengan rancangan yang telah dibuat.

\section{1) Alpha Testing}

Alpha testing merupakan pengujian aplikasi oleh pembuat baik dari segi interface, menu, fungsi tombol, gambar, teks dan audio yang dihasilkan. Hasil dari pengujian dapat dilihat pada Tabel X.

\section{TABEL X. ALPHA TESTING}

\begin{tabular}{|c|c|c|c|}
\hline No. & Fungsi & Deskripsi & Hasil \\
\hline 1. & Splash Screen & $\begin{array}{l}\text { Tampilan yang } \\
\text { muncul beberapa } \\
\text { detik ketika user } \\
\text { membuka aplikasi. }\end{array}$ & Sesuai \\
\hline 2. & $\begin{array}{lll}\text { Edit Text } & \text { Isi } \\
\text { Nama } & & \\
\end{array}$ & $\begin{array}{l}\text { Menu untuk mengisi } \\
\text { nama. }\end{array}$ & Sesuai \\
\hline 3. & Tombol Masuk & $\begin{array}{l}\text { Tombol untuk } \\
\text { menuju ke tampilan } \\
\text { menu utama. }\end{array}$ & Sesuai \\
\hline 4. & Menu Utama & $\begin{array}{l}\text { Menu yang } \\
\text { menampilkan tombol } \\
\text { untuk bermain game, } \\
\text { tentang game dan } \\
\text { cara bermain game. }\end{array}$ & Sesuai. \\
\hline 5. & $\begin{array}{l}\text { Tombol } \\
\text { Tentang Game }\end{array}$ & $\begin{array}{l}\text { Membuka dan } \\
\text { menampilkan isi } \\
\text { menu tentang game. }\end{array}$ & Sesuai. \\
\hline 6. & $\begin{array}{l}\text { Tombol Cara } \\
\text { Bermain }\end{array}$ & $\begin{array}{l}\text { Membuka dan } \\
\text { menampilkan isi } \\
\text { menu cara bermain } \\
\text { game. }\end{array}$ & Sesuai. \\
\hline 7. & $\begin{array}{l}\text { Tombol Mulai } \\
\text { Game }\end{array}$ & $\begin{array}{l}\text { Menampilkan menu } \\
\text { pilih pelajaran. }\end{array}$ & Sesuai. \\
\hline 8. & Tombol Keluar & $\begin{array}{l}\text { Tombol konfirmasi } \\
\text { untuk menutup atau } \\
\text { kembali ke dalam } \\
\text { game. }\end{array}$ & Sesuai \\
\hline 9. & $\begin{array}{l}\text { Menu Pilih } \\
\text { Pelajaran }\end{array}$ & $\begin{array}{l}\text { Membuka dan } \\
\text { menampilkan } 3 \text { menu } \\
\text { pilih pelajaran. }\end{array}$ & Sesuai \\
\hline 10. & $\begin{array}{l}\text { Tombol } \\
\text { Matematika, }\end{array}$ & $\begin{array}{l}\text { Menampilkan soal- } \\
\text { soal Matematika, }\end{array}$ & Sesuai \\
\hline
\end{tabular}

\begin{tabular}{|c|l|l|c|}
\hline No. & Fungsi & Deskripsi & Hasil \\
\hline & $\begin{array}{l}\text { Bahasa } \\
\text { Indonesia, } \\
\text { Bahasa Inggris }\end{array}$ & $\begin{array}{l}\text { Bahasa Indonesia, } \\
\text { Bahasa Inggris }\end{array}$ & \\
\hline 13. & $\begin{array}{l}\text { Halaman Nilai } \\
\text { Matematika, } \\
\text { Bahasa } \\
\text { Indonesia, } \\
\text { Bahasa Inggris }\end{array}$ & $\begin{array}{l}\text { Menampilkan nilai } \\
\text { Indonesia, Bahasa } \\
\text { Inggris yang sudah } \\
\text { diperoleh player. }\end{array}$ & Sesuai \\
\hline 16. & $\begin{array}{l}\text { Tombol Main } \\
\text { Lagi }\end{array}$ & $\begin{array}{l}\text { Membuka kembali } \\
\text { soal pertanyaan. }\end{array}$ & Sesuai \\
\hline 17. & $\begin{array}{l}\text { Tombol Menu } \\
\text { Utama pada } \\
\text { Halaman Nilai }\end{array}$ & $\begin{array}{l}\text { Membuka kembali } \\
\text { menu utama. }\end{array}$ & Sesuai \\
\hline
\end{tabular}

\section{2) Beta Testing}

Tahap pengujian beta testing ini, diambil dari hasil kuesioner penilaian kemenarikan aplikasi game edukasi anak dengan total pertanyaan 8 yang diisi oleh siswa kelas 1 (satu) Sekolah Dasar Negeri Sukamandi II (SDN SUKAMANDI II) dengan jumlah siswa 32 orang. Rumus untuk menghitung kualitas atau kelayakan aplika menggunakan rumus (1) $[6]$ :

$$
\begin{aligned}
& \text { Presentase nilai } \%= \\
& \frac{\text { Rata-rata }}{\text { Nilai tertinggi }} \times 100 \%
\end{aligned}
$$

Jumlah pertanyaan dan presentase penilaian dari masing-masing pertanyaan dapat dilihat pada Tabel X.

\begin{tabular}{|c|c|c|c|c|}
\hline \multirow{2}{*}{ No. } & \multirow{2}{*}{ Pertanyaan } & \multicolumn{2}{|c|}{ Skor } & \multirow{2}{*}{$\%$} \\
\hline & & Total & Max & \\
\hline 1. & $\begin{array}{l}\text { Apakah kamu suka } \\
\text { dengan aplikasi game } \\
\text { edukasi anak? }\end{array}$ & 100 & 100 & $100 \%$ \\
\hline 2. & $\begin{array}{l}\text { Apakah kamu tertarik } \\
\text { untuk menggunakan } \\
\text { game edukasi? }\end{array}$ & 97,3 & 100 & $97,3 \%$ \\
\hline 3. & $\begin{array}{l}\text { Apakah menurut } \\
\text { kamu tampilan game } \\
\text { edukasi ini menarik? }\end{array}$ & 100 & 100 & $100 \%$ \\
\hline 4. & $\begin{array}{l}\text { Menurut kamu } \\
\text { apakah aplikasi ini } \\
\text { mudah dimainkan? }\end{array}$ & 94,6 & 100 & $94,6 \%$ \\
\hline 5. & $\begin{array}{l}\text { Apakah pembelajaran } \\
\text { dengan aplikasi game } \\
\text { edukasi ini } \\
\text { menyenangkan? }\end{array}$ & 100 & 100 & $100 \%$ \\
\hline 6. & $\begin{array}{l}\text { Apakah kamu suka } \\
\text { dengan musik yang } \\
\text { ada pada aplikasi } \\
\text { game edukasi anak? }\end{array}$ & 97,3 & 100 & $97,3 \%$ \\
\hline 7. & $\begin{array}{l}\text { Apakah kamu suka } \\
\text { dengan gambar yang } \\
\text { ada pada aplikasi } \\
\text { game edukasi anak? }\end{array}$ & 100 & 100 & $100 \%$ \\
\hline 8. & $\begin{array}{l}\text { Apakah kamu suka } \\
\text { dengan animasi } \\
\text { kartun yang ada pada } \\
\text { aplikasi game edukasi } \\
\text { anak? }\end{array}$ & 100 & 100 & $100 \%$ \\
\hline & Total & 789,2 & 800 & $98,6 \%$ \\
\hline
\end{tabular}

TABEL XI. BETA TESTING 


\section{Penggunaan Aplikasi Game Edukasi}

Aplikasi digunakan oleh siswa kelas 1 (satu) Sekolah Dasar Negeri Sukamandi II (SDN SUKAMANDI II) dengan jumlah siswa 32 orang, sebelum siswa mencoba aplikasi game edukasi, siswa melaksanakan psikotes terlebih dahulu. Setelah itu, siswa mencoba aplikasi game edukasi yang telah dibuat dengan mengerjakan soal-soal dari tiap pelajaran, jika semua soal telah dikerjakan maka diperoleh nilai dari masing-masing pelajaran, dapat dikalkulasikan pada rumus (2).

\section{Presentase pengetahuan siswa $=$ $\frac{\text { Rata-rata }}{\text { Nilai tertinggi }} \times 100 \%$

Berdasarkan hasil pengujian aplikasi didapatkan hasil, sebagai berikut:

1. Pengujian Manual atau Tanpa Aplikasi

Setelah dilakukan pengujian secara manual didapatkan hasil pemahaman belajar anak pada pelajaran Matematika sebesar $86,2 \%$, Bahasa Indonesia dengan presentase $85,3 \%$ dan Bahasa Inggris didapatkan persentase sebesar 73,8\%.

2. Pengujian Menggunakan Aplikasi

Dari pengujian menggunakan aplikasi didapatkan hasil persentase pemahaman belajar anak pada pelajaran Matematika yaitu 97,8\%, Bahasa Indonesia 95,6\% dan Bahasa Inggris $92,5 \%$.

Dari pengujian tersebut dapat disimpulkan bahwa pemahaman belajar anak mengalami peningkatan setelah menggunakan aplikasi game edukasi pemahaman belajar anak yaitu $11,6 \%$ pada pelajaran Matematika, 12,5\% untuk pelajaran Bahasa Indonesia dan 18,7\% pada pelajaran Bahasa Inggris, sehingga aplikasi ini efektif untuk meningkatkan kemampuan belajar anak.

\section{F. Distribusi (Distribution)}

Pada tahap ini, aplikasi disimpan dalam suatu media penyimpanan yaitu google drive, sehingga ketika user ingin bermain game edukasi ini, diberikan link dari google drive untuk menginstal aplikasi game edukasi pemahaman belajar anak. Di bawah ini pendistribusian aplikasi game edukasi pemahaman belajar anak:

1. Upload aplikasi ke Google Drive, lalu copy link game tersebut dan link tersebut disederhanakan menggunakan bit.ly seperti pada Gambar 19 dan 20 .

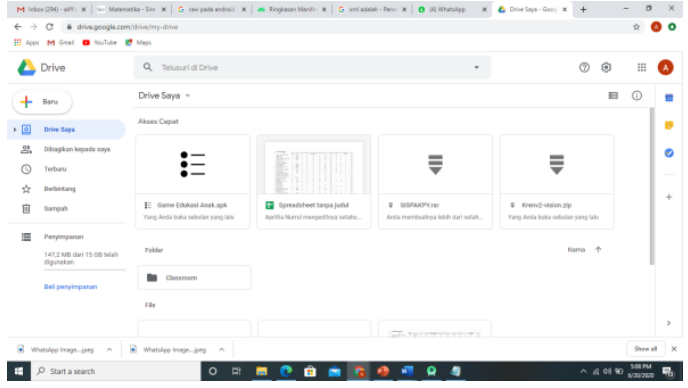

Gambar 19. Pengunggahan Aplikasi ke Google Drive

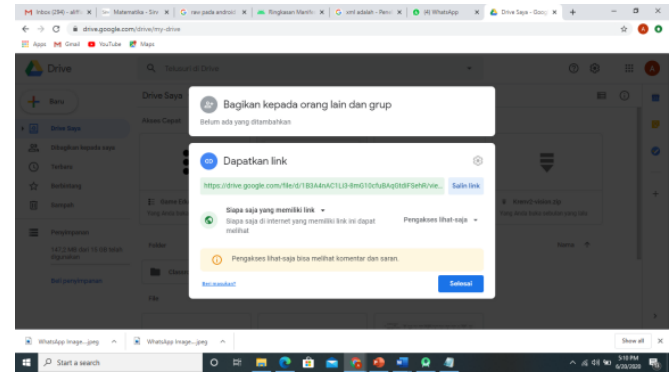

Gambar 20. Pengambilan Link Game Edukasi pada Google Drive

2. Langkah selanjutnya, penyederhanaan link pada Bitly Management. Link yang telah diambil dari Google Drive diatur pada web bitly management, kemudian atur nama aplikasi, kemudian klik save, sehingga didapatkan link https://bit.ly/2W5lj7A dan sudah dapat diakses oleh user untuk mengunduh aplikasi, penyederhanaan link google drive dapat dilihat pada Gambar 21.

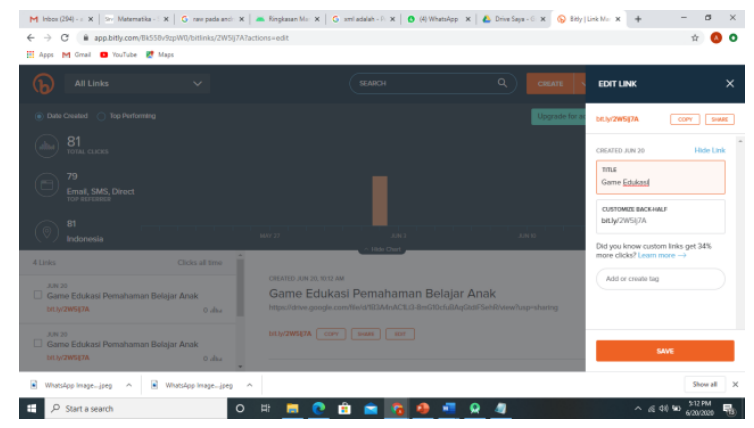

Gambar 21. Penyederhanaan Link Pendistribusian Aplikasi

\section{KESIMPULAN DAN SARAN}

Berdasarkan penelitian yang telah dilakukan dalam menerapkan metode finite state machine pada game edukasi, dapat disimpulkan bahwa untuk mengatasi permasalahan anak yang dalam pelajaran kesulitan berkembang, mudah bosan dan tidak ada kemauan berusaha yaitu dengan cara menyisipkan media belajar interaktif berupa game edukasi. Permainan selesai apabila user telah menyelesaikan soal pertanyaan pada setiap tahap. 
Dengan adanya aplikasi game edukasi efektif untuk meningkatkan kemampuan belajar anak, mengurangi rasa bosan pada anak ketika belajar, mampu mengembangkan kemampuan belajarnya dan dapat meningkatkan kemauan berusaha untuk belajar.

Saran yang diusulkan setelah dilakukan penelitian ini, yaitu dapat menggunakan metode sistem kontrol lain misalnya Proportional Integral Derivative (PID), Jaringan Saraf Tiruan (JST), logika fuzzy dan lain sebagainya. Aplikasi ini diharapkan dapat dievaluasi menggunakan tahap pengujian lainnya seperti white box dan black box testing dan dapat dikembangkan lagi dengan dipublikasikan melalui Playstore atau Appstore agar dapat di manfaatkan oleh khalayak umum.

\section{REFERENSI}

[1] Fahmi, Z. (2018). Rancang Bangun Aplikasi Pembelajaran Bahasa Inggris Berbasis Android Untuk Anak - Anak (Skripsi). Universitas Singaperbangsa Karawang, Karawang.

[2] Huda, A. S. (2016). Game Edukasi Cepat Tepat Dengan Metode Finite State Machine (FSM) pada Smartphone. (Skripsi). Universitas Islam Negeri Maulana Malik Ibrahim, Malang.

[3] Neyfa, B. C., Tamara, D. Perancangan Aplikasi E-Canteen Berbasis Android Dengan Menggunakan Metode Object Oriented Analysis \& Design (OOAD). Jurnal Penelitian Komunikasi dan Opini Publik. 2016; Vol. 20 No.1: 83-91.

[4] Ramadhan, H. F., Sitorus, S. H., Rahmayuda, S. Game Edukasi Pengenalan Budaya Dan Wisata Kalimantan Barat Menggunakan Metode Finite State Machine Berbasis Android. Coding: Jurnal Komputer dan Aplikasi. 2019; Volume 07, No. 1: 108-119.

[5] Sutopo, H. (2011). Aplikasi Multimedia Dalam Pendidikan. Jakarta: Gading Serpong.

[6] Wirawan, R., Awal Nur, M., \& Syahraeni, R. (2020). Aplikasi Pembelajaran Matematika Interaktif Berbasis Multimedia. JARTIKA : Jurnal Riset Teknologi Dan Inovasi Pendidikan, 3(1), 75-83. 